\title{
BEING DISABLED PERSONS IN SPAIN: POLICIES, STAKEHOLDERS AND SERVICES ${ }^{1}$
}

\author{
Antonio Citarella *; Ana Isabel Sánchez Iglesias**; Sergio González Ballester*; Ana Amparo Gentil \\ Gutiérrez**; Juan José Maldonado Briegas***; Florencio Vicente Castro*;Jerónimo González Bernal **; \\ * Investigador INFAD \\ ** Investigador INFAD y Prof. Univ. de Burgos \\ $* * *$ Univ. de Extremadura. Badajoz. \\ * Contacto para el artículo: antonio.citarella1@istruzione.it
}

Recepción Artículo: 15 abril 2020

Admisión Evaluación: 17 abril 2020

Informe Evaluador 1: 17 abril 2020

Informe Evaluador 2: 119 abril 2020

Aprobación Publicación: 20 abril 2020

\begin{abstract}
This study aims to review the historical path of policies that have bring Spanish country to develop an advanced system of protection and integration of disabled people in its society. Through the analysis of the three fundamental general laws, we argue as the Spanish legal framework for disability - rooted in its Constitutional Chart- transposed at national and local level the major UN and EU supranational legislation in the matter. In addition, we get a look also on the main stakeholders that facilitate the access of disabled people to services provided by national and local government. Finally, appendix 1 and 2 exemplify concrete measures in terms of aids and benefits for disabled people and policies in the field of sport and physical activities for them respectively. In theoretical terms, the review shows that the actual Spanish legal system -and its services system- agrees with the internationally shared social paradigm of disability and overcame the rehabilitation or medical model in which rights and integration of disabled people were not fully acknowledged.
\end{abstract}

Keywords: protection and integration of disabled people,

\section{RESUMEN}

El propósito de este trabajo es resumir el camino histórico de las políticas que llevaron España a desarrollar un sistema avanzado de protección y integración de personas con discapacidad en su sociedad. A través de análisis de las tres fundamentales leyes generales, nosotros argumentamos como es el marco legal español para discapacidad -arraigado en su Carta Constitucional- formuló a nivel nacional y local la mayor legislación supranacional de UN y EU en esta materia. Además, presentamos las principales partes implicadas que facilitan el acceso de personas con discapacidad a los servicios que el gobierno nacional y local proporcionan a los discapacitados. Finalmente, Ios puntos 4 y 5 ejemplifican respectivamente las medidas concretas de ayudas y beneficios para persona con discapacidad y las políticas para el deporte y la actividad física. Teóricamente, el resume muestra como 
el actual sistema legal español - y su sistema de servicios- concuerdan con el paradigma social de discapacidad compartido a nivel internacional y fundamenta el modelo de rehabilitación o médico en el cual los derechos y la integración de las personas con discapacidad que no eran enteramente reconocidos y ahora ya lo son.

Palabras clave: protección y integración de personas con discapacidad

\section{O.- INTRODUCTION}

In Spain, the actual legal framework, aimed to ensure the respect of rights of person with disability (PwD) and their full integration in the society, descend from both nationally and supranationally general norms and declarations of principles which have led to a temporally progressive promulgation, adaptation and improvement of specific policies at national and local level. Although reflecting on the medical conception of disability, the article 49 of Spanish Constitutional Charter is the national highest legal reference that states the rights of PwD. Hence, already in its act constitutive dated 1978, Spain explicitly acknowledges the protection, cure and integration of PwD and delegates to public power the role of legislate for these purposes. The article 49 of Spanish Constitutional Charter implements the indications of the Declaration of the Rights of People with Mental Delay (1971) and the Declaration of the Rights of Disabled People (1975) both states by United Nations. Therefore, at supranational level, the sources inspiring Spanish legislation for PwD must be sought in the provisions of the United Nations and, subsequently, of the European Union.

\section{HISTORICAL SPANISH LEGAL FRAMEWORK RELATED TO PWD}

The first specific policy on disability matter ascend to 7 April 1982 with the Law of Social Integration of Disabled, known as LISMI in Spain. This law is a regulatory measure that applies the constitutional provision and at the same time according with the Action Program of United Nations adopted in the same year (Jiménez \& Huete, 2010). LISMI may be considered as a pioneer reference obliged for the subsequent legislation acknowledging a number of social rights for PwD and establishing criteria in order to qualify them (Verdugo, Vicent, Campo \& Jordán de Urríes, 2001). However, LISMI focused our actions on the provision of a number of economic and assistances services for PwD considered individually needed of protection due to disability and, therefore, acting yet within of rehabilitation paradigm and it does not contemplate interventions aimed to change general social conditions which hinder integration for PwD in Spanish society (Toboso-Martín, 2013).

The subsequent specific general Law of Equality of Equal Opportunity, non-Discrimination and Universal Opportunity (LIONDAU in Spain) - promulgated in 2003- fits the disability European policy framework emerging in the 90s. In this regard, Hvinden and Halvorsen (2003) noted: "Since the mid-90s EU has developed a new broader disability strategy, together with a stronger ambition to influence the policies and practices of member states." (p. 204). Accordingly, LIONDAU transposed in the Spanish legal system the provision of Amsterdam Treaty of 1997 (specifically article 13) and of the Council Directive of November 2000 establishing principles of non-discrimination and equal opportunities for integration in the society. The core of these European initiatives is represented by the affirmation, volition and intentionality in combating strongly all forms of discrimination in order to consent to all people with diversity and disability to fully enjoy of the rights guaranteed by European citizenship. Should be noted that both Amsterdam Treaty and the Directive of November 2000 were two legal instruments which show a more effective legal competence of European Union (Waldschmidt, 2009) - in this case applied to the matters of social policies and equal rights. Acknowledging EU measures, LIONDAU marked the initial overcoming of medical prospective of disability and it opens the progressive implementation of actions rooted within the social model of disability. Indeed, several measures are introduced in which the passage toward social model are clearly evident. Among these, LIONDAU establishes that public powers are obliged to lead a number of actions aimed to eliminate all forms of discrimination and the government is obliged to gradually and progressively eliminate all barriers in terms of environments, products and services that can be an obstacle to the full rights of citizenship for disabled persons. In addition, public administrations are obliged to promote initiatives in order to raise awareness towards PwD, as well as formative actions to develop new technology for PwD and 
PSICOLOGÍA Y CRECIMIENTO HUMANO

ensuring them equal opportunity in the society (Garcia \& Palacios, 2005). In order to implement these norms, the II Plan of actions for Disabled People has been activated, and based on the following several principles: (1) rights promotion; (2) autonomy and independent life; (3) integration and normalization; universal accessibility and design for all; (4) diversity respect and gender perspective; (5) quality life; (6) participation and civic dialogue (Egido, 2006). Finally, the application of LIONDAU has determined the transposition in the Spanish legal system of the Employment Equality Directive 2000/78CE with which European Union prohibits discrimination of PwD in the workplace.

\section{SPANISH LAW IN FORCE FOR ACCESSIBILITY OF PWD TO HEALTH, EDUCATION AND OTHER RELEVANT SERVICES}

The latest general Spanish policy specifically dedicated to PwD was promulgated in 2013. The General Law on the Rights of Persons with Disability (LGD in Spain) contains several improvements with respect to LIONDAU and incorporates in the Spanish legal system the provisions of the United Nations Convention on the Rights of Persons with Disability (CRPD) promulged in the 2008. CRPD is the highest document that states internationally the rights of PwD. Lord and Stein (2008) analyzed the CRPD with regard of its incorporation at national level. First of all, they claimed that nations ratifying the Convention have a number of several general obligations aimed to ensure the rights of persons with disability in their countries. States are required to adopt measures to promote and implement the concept of inclusivity in their legal framework for disability. Moreover, national legal systems must incorporate the general principles and framing of disability of Convention in which categorically is affirmed the social model of disability. In the incorporation of obligations and general principles a special attention must be nationally paid to adopt measure to ensure the contrast to disability-based attitudes toward discrimination and, importantly, for women and children. Conversely, alongside the historically well-established freedoms for PwD, the Convention provides indications for the adoptions of measures at national level that ensure new freedoms as the rights to independent life, mobility etc. A very important provision consists in the monitoring at national level of implementation of Convention in which disabled people and their representative organisms have the right to participate. Finally, in order to facilitate the international monitoring of Convention, states must also organize a system of collecting of longitudinal data and statistics. In all of their activities, nations will be assisted by supranational entities and they will favor a climate of collaborations among them (e.g. trough international meeting or conference aimed to change opinions and shared good practices).

As above mentioned, the General Law on the Rights of Persons with Disability (LGD in Spain) is the specific policy that Spain adopted to adequate national legal system to new provisions of Convention. It is composed by three main sections (Títulos in Spanish), with addition of one preliminary part where PwD are identified and the areas of interventions indicated. For the purpose of this study we deep only the first iitulo concerning the rights of PwD and the obligations for public powers in order to guarantee these rights. PwD are guaranteed in regard of their rights to health, education, employment, independent life, integral attention, social protection and participation to public affairs.

The law prescribes Spanish health system to provide a variety of services for guaranteeing to PwD health assistance. A multidisciplinary specialized equip takes charge of PwD and provides assistance with aim to permit the basic service for a full integration and inclusion in the society. This equip is composed by professionals in specific medical fields related to the disability of the person requiring assistance and by a variety of socio-psychological professionals both having received specific education and training in the field of disability and they are requested to continue their learning according to scientific advances. For this purpose, public administrations will establish programs of lifelong learning for all professional that operate in the health system.

The right of education is guaranteed in Spain keeping into account of the internationally attention dedicated to inclusive education. Haug (2017) noted that "since the Salamanca Statement in 1994, most European countries have acknowledged that inclusive education is an important premise to secure equal education rights for all persons with varied special educational needs". In this regard, the article 18 of LGD, in subsection 2, claims that 
"appertain to educational administrations assuring an inclusive educational system at all level of education [...]" (p.206). For this purpose, the subsection 3 of the same article specifies that schooling for PwD must be assured principally in ordinary schools and only exceptionally in special schools. Anyway, in the latter case, parents can express their opinion concerning the choice of entrusting their son or daughter to teachers operating in special schools. The law guarantees also adequate education for disabled youth hospitalized and for youth enrolled in university courses. As for health professionals, public administrations will carry out a number of programs of sensibilization, information and training aimed to enrich the competence in the field of disability and special needs of teachers and other educational professionals - included managers - that operate in the Spanish educational system.

LGD prescribes that disabled persons are beneficiaries of the same rights to employment provided to people without disability. In this regard, one is stressed in the importance to prevent direct and indirect discrimination and fight against all forms of bullying and mobbing in the workplace. A number of measures are established to favor the access to employment for disabled people. The more effective are surely the legal reservation of jobs for disabled people in public and private companies. Alongside the occupation of disabled people in ordinary jobs, the law prescribes the opportunity to take advantage of protected work in special companies that associate the pursuit of economic profit to the inclusion of PwD.

Health, education and employment all work together to ensure the independence of life for disabled people that represents the goal of policies for these individuals as specified in the Convention transposed in Spanish LGD. Therefore, an integral attention and social protection is guaranteed to PwD for all aspects of life, including political and civic participation.

In order to make concretely independence life for disabled people through the effective exercise of aforementioned rights, the law splits other important issues. Firstly, a central focus has surely the provision of obligations for public and private sectors to adequate their environmental spaces to allow mobility and use of them for people with disability. Second, a variety of economic benefits are provided to PwD -including pensions- to facilitate their participation into society life. Finally, the law prescribes a series of fines to punish public and private companies and citizens that do not respect the legal prerogative of PwD.

In order to define and coordinate public policies for PwD, LGD has established a National Council for Disability. This organ collaborates with a number of several associations operating in Spain with aim to promote the rights of disabled persons.

Another important national organ is represented by the State Disability Observatory (OED in Spanish) which has a technical function of compilation, systematization, updating, generation of information and dissemination related to the field of disability. Every year the State Disability Observatory realizes a general report concerning the situation and evolution of disability in Spain. This report also includes statistical data, with special attention to gender, and it is sent to National Council for Disability for knowledge and debate.

In this regard, we will conclude our excursus on Spanish disability legal framework briefly getting a look to the latest report, namely the OED Olivenza Report 2019. This report it is very important because offers the more recent evolution of Spanish policies and jurisprudence in which, importantly, we can find a proposal of change of the article 49 of Spanish Constitution dedicated to disabled persons. Hence, Spain is getting ready to complete its national legal course and incorporation of UN Convention for disability making the social model of disability a constitutional prerogative and fully considering rights for disabled people as fundamental rights. In this regard, an important function is assuming the People Defensor, a constitutional organ used as controlling respect of fundamental rights in Spain. We can find in its 2018 report some important decisions of People Defensor regarding disabled people.

\section{STAKEHOLDERS}

The access to services for disabled people in Spain is therefore configured as priority administrated by public authorities and based on international and Constitutional principles. Hence, the main stakeholders that facilitate 
the access to protection and integration services are represented by a number of public actors operating in health, education and other several sectors. However, cannot be underestimated the crucial role of directly related associations of disabled people. These are coordinate by the Spanish Committee of Representative of Disabled People (CERMI). It is a representative platform established to defend rights and interests of disabled people, officially designed by Spanish State in order to independently operate for the actuation of UN Convention (OED, 2019). Many associations directly or indirectly promote a number of several community-based projects- also promoted by European Union- to improve the life condition of disabled people in Spain. For example, INFAD is participating to an Erasmus project denominated PREG-EQUAL and concerning the reproductive health linked to maternity for women with disability. PREG-EQUAL project has the following objectives:

- Through specific training programmes, improve the knowledge and the self-awareness that women with disability and their families have on reproductive choices, sexual health, voluntary interruption of pregnancy (VIP) and maternal health

- Through specific training programmes, improve the psychological and emotional support and the quality of the information for women with disability, promoting empowerment actions towards their families and their husbands/partners

- Improve the access and the quality of the health services for women with disability through specific training addressing pre-natal and maternal health professionals

- Through institutional partnerships, conduct a qualitative and quantitative research in each partner country on the access and the quality of prenatal and maternity services for women with disability

This is an example of special attention dedicated to the association of two important rights: disability and gender. Indeed, women with disability are often interested by multi-discrimination and therefore disability legislation -at national and supranational level- has even more integrated the rights of PwD with women rights.

In addition to official organs and associations, it cannot be forgotten that disability in Spain - as in all Mediterranean countries - family is the other fundamental stakeholder for the integration of disabled people in the society and for decision-making related to the guidance that disabled persons receive (Huete, Huete \& Martín, 2015). In this regard, we believe important concluding this paper reporting the incipit of the preface of Alberto Durán - General Secretary of CERMI - to the book "Fundamental Rights and Disability" (Martínez-Pujalte, 2016). He claims:

The history of disability in Spain is built on the work and commitment of representative organizations of people with disabilities and their families. This is a story of effort, unity, commitment and also solidarity, which could be considered an exceptional example of civil society organization outside our borders.

\section{4.- LIST OF SPECIFIC HEALTH AND EDUCATIONAL AND OTHER RELEVANT SERVICES FOR PWD.}

\subsection{Technical Aids and Assistive Devices offered to PwDs in Spain}

They try to facilitate the development and personal autonomy of people with disabilities at home (adaptations in the house), on the street (adaptations in the means of transport) and in their socio-environmental environment. More information about these grants on the website of the Institute for the Elderly and Social Services (IMSERSO), where you can find information on the State Center for Personal Autonomy and Technical Aids (CEAPAT), which has a catalog of technical grants. Website addresses: IMSERSO: www.imserso.es CEAPAT: www.ceapat.org

\subsection{Care Centers for people with disability}

There are establishments where the rehabilitation and/or mental and/or physical recovery of people with some type of disability is sought.

Centers for people with physical disabilities:

- Centers for care for people with physical disabilities (CAMFS): 
their scope is national, so they can be accessed by people with disabilities from anywhere in Spain. The IMSERSO manages the CAMFS with a total of 608 places, 560 internships and 48 half-board, they are located in Alcuéscar (Cáceres), Ferrol (A Coruña), Guadalajara, Leganés (Madrid) and Pozoblanco (Córdoba).

- Recovery centers for people with physical disabilities (CRMF).

They are state-level centers that, starting from an integrated approach to rehabilitation, provide a set of recovery services with medical-functional, psycho-social content and vocational guidance and training for people with physical or sensory disabilities of working age. These services are offered in boarding school, half board or outpatient, according to the personal circumstances and needs and interests of the users. The IMSERSO manages 6 CRMFs, with a total of 613 places, of which 456 are boarding schools and 157 are half board or ambulatory, and are located in Albacete, Bergondo (A Coruña), Lardero (La Rioja), Madrid, Salamanca and San Fernando (Cádiz)

\subsection{Telephone intermediation center}

The telephone intermediation center, belonging to the Ministry of Health, Social Services and Equality, provides its service by facilitating telephone communication between deaf or deaf people with hearing and / or speech disabilities, who are users of text telephones, mobile phones, fax or videoconference, with listeners who use conventional telephones uninterruptedly, 24 hours a day and 365 days a year.

The cost of calls to the center is treated as a local rate, for calls made from anywhere in the country. The communication telephone numbers are as follows:

- Listener: 901558855

- Text telephone (DTS): 901551010

- Text telephone (DTS-URGENCIAS): 900211112

- Text telephone (AMPER): 901568866

- SMS: 610444991

- FAX: 901515011

- Videoconference: 913750498

- Email: cii@sertel.es

\subsection{Education}

Individual and direct aid for special education, exemption from fees in some universities, personal support for class attendance at some universities, aid for transportation and dining. Aid in the field of the General State Administration, the Ministry of Education, Culture and Sport:

1.-Non-University: Call for individual aid aimed at students with a specific need for educational support to attend to ADHD cases, any disability and conduct disorders, as well as subsidies to large families with some of the above, always within economic thresholds for income and wealth.

2.-University: Call for general and mobility scholarships in each academic year, for university students, and within them there is an article dedicated to special scholarships for students affected by a disability, with the following characteristics:

- Students affected by a legally qualified degree of disability equal to or more than 65 percent may reduce the teaching load and increase the number of years to complete the studies.

- When the reduced enrollment is not used and the student formalizes the enrollment in all the credits, the amounts of the scholarships that correspond to them will increase by 50 percent, with the exception of the enrollment scholarship.

- To calculate the income, deductions will be applied depending on whether the student and / or member of the family unit is a person with disability, as well as the degree of disability and in different amounts.

In the case of Public Universities, additional exemption from public fees and prices in studies leading to obtaining a university degree is established in Organic Law 6/2001 of Universities.

More information, on the website of the Ministry of Education and Vocational Training: www.educacionyfp.gob.es 
On the other hand, the Universia Foundation is worth highlighting with the following scholarships for university students with disabilities:

- Access: aimed at students who are enrolling for the first time in undergraduate university studies.

- Progress: aimed at students who have already entered university.

- Mobility: aimed at students who, by virtue of an exchange program of the university itself, wish to carry out a training period, at least one term, at a university with an international destination.

- From the ADOP Plan: Aimed at student athletes with disabilities assigned to the ADOP Plan, who are going to enter the university or who are already studying at the university.

- From "LaLiga Genuine Santander": aimed at students members of any Sport Club that participates in LaLiga Genuine Santander that enrolled in the 2019/2020 academic year in specific university training for "young people with intellectual disabilities".

More information on the Fundación Universia website: www.fundacionuniversia.net

\subsection{Transport:}

Special transport card from The Madrid Regional Transport Consortium has season tickets for people with disabilities: this is a Transport Subscription with a reduced rate, aimed at users with a disability degree equal to or more than $65 \%$.

RENFE: "Gold card" beneficiaries are pensioners over 18 years of age, in a situation of total or absolute permanent physical or mental disability or major disability, formally declared, as well as people with disabilities with a disability degree equal to or more than $33 \%$.

For these people, a card will be issued with the "and companion" print that allows another person to travel enjoying the same discount conditions. This card allows a discount of between 25 to $40 \%$ in the rates. More information on the RENFE website:

www.renfe.com/viajeros/feve/Descuentos/tarjetadorada.html

All information is retrieved on the guide: "Benefits and aid for disabled persons". OAIDS Disability Care Office. Website: oadis.vpsocial.gob.es

\section{5.- SPORT AND DISABILITY IN SPAIN}

\subsection{Policies}

Community development policies have, among their objectives, the inclusion of people with disabilities. A good instrument to achieve this is through adapted sport (Martínez-Ferrer, 2004); understanding adapted sport as one that uses other means than the usual ones to allow athletes with physical, intellectual or sensory disabilities to safely practice their chosen sport (Martínez-Ferrer, 2010).

The 2004 International Paralympic Committee Assembly approved the strategic direction of promoting the integration of the different Paralympic sports in the international sports federations.

The UN declared 2005 as the International Year of Sport and Physical Education (UN, 2003) and the following year sport and physical activity were recognized as human rights for people with disabilities in the "Convention on the Rights of Persons with Disability "of the UN (UN, 2006). In 2007, as a result of global awareness of disability, the International Disability in Sport Working Group was created, which promotes and supports the rights of people with disabilities to physical activity and sports and competitive practice in world regions (International Disability in Sport Working Group, 2007).

In Spain, the Superior Sports Council (CSD) proposed the "Comprehensive Plan for Physical Activity and Sport" (PIAFD) for the 2010-2020 period (Superior Sports Council 2009). Two of its objectives are to promote sport among people with disabilities and groups at risk of exclusion. At the 1st National Conference on Adapted Sports (2009) a structural integration plan was presented, and promoted by the CSD and the Spanish Paralympic Committee (CPE), in collaboration with the Spanish sports federations. Subsequent scientific competitions have 
dealt with the subject in an extensively way: the "European Congress of Adapted Physical Activity-EUCAPA" (2010), with the table on "Integration and Inclusion", and at the 2nd National Conference on Adapted Sport (Valencia).

Likewise, in Spain the entities for the promotion of sports are defined in article 42 of the Law on Sports, where are included the associations of clubs or entities that have the exclusive purpose of promoting and organizing physical and sports activities, for recreational, educational or social purposes. In this section functions, policies, strategies and / or actions regarding the promotion of the sport of PwD are exposed, carrying out an analysis in the three levels of public administration of the State: national, regional and local.

\section{2.- State administrations with responsibility for physical activity, sport and disability.}

\subsection{1.- Ministry of Health and Social Welfare}

The Ministry of Health, Consumer Affairs and Social Welfare is responsible for proposing and executing the policy of the Spanish State Government regarding health, planning and health care and consumption, as well as exercising the powers of the General State Administration to ensure citizens the right to health protection. In addition, it has competences in matters of social cohesion and inclusion, family, child protection and care for dependent or disabled people. In this last matter, its performances are divided into four groups:

1. Benefits for people with disabilities (social benefits, non-contributory pensions, etc.).

2. Services, among which the State Disability Observatory (OED), the Office for the Attention to Disability (OADIS), the Telephone Intermediation Center, the Recovery Centers for people with Physical Disabilities (CRMF, $n=6)$. ), the Centres for Attention to People with Physical Disabilities (CAMF, $n=5$ ), the State Reference Centres (CRE, $n=5$ ), the Spanish Centre for Subtitling and Audio-description (CESyA), the Spanish Documentation Centre on Disability (CEDD) 1, as well as tourism and spa activities for people with disabilities.

3. Information actions on disability, among which it should be highlighted the National Council on Disability (regulated by Royal Decree 1855/2009, of December 4), the application of the Convention in the Spanish State, the Disability Survey, Personal Autonomy and Dependency Situations (AGE), or the Action Plan of the Spanish Strategy on Disability 2014-2020, among others.

4. Protection of rights (managed by OADIS) and subsidies to the third sector (NGOs).

\subsection{2.- Royal Board on Disability}

The Royal Board on Disability is an autonomous body attached to the aforementioned Ministry of Health, Consumer Affairs and Social Welfare, whose mission is to promote the prevention of deficiencies, rehabilitation and social integration of people with disabilities. Furthermore, its mission includes facilitating exchange and collaboration among the different public administrations, as well as between these and the private sector; provide support to organizations, entities, specialists and promoters in the fields of studies, research and development, information, documentation and training, as well as issuing technical opinions and recommendations on matters related to disability. The Royal Board on Disability is regulated by Law 14/2000 on Fiscal, Administrative and Social Order Measures (article 57).

\subsection{3.- Ministry of Education}

To refer to the policies that currently exist in education in relation to the sport of people with disabilities, it is necessary to start from the current regulation, Organic Law 8/2013 for the improvement of educational quality (LOMCE). In this law, reference is made to the fact that the law aims to achieve "equity, which guarantees equal opportunities for the full development of the personality through education, educational inclusion, equal rights and opportunities that help to overcome any discrimination and universal accessibility to education ".

In this regard provision 3.1 of the Law on Sports, stipulates that "the general programming of teaching will include physical education and the practice of sport", therefore it is necessary to turn to the analysis of the edu- 
cational curricula of this subject in the different stages to know the actions regarding care and inclusion of students with disabilities

\subsection{4.- Higher Sports Council}

The government section dedicated to sports is located in the Ministry of Culture and Sport and is organized in seven areas: associations and federations, high-competition sport, sport and health, sport and society, sports facilities, women and sports, and sports promotion. The policies and management of these areas rest with the Higher Sports Council, to which Law 10/1990 grants the highest authority in the execution of the policies of the Government of Spain in this matter. The last known Comprehensive Plan for Physical Activity and Sport (A + D Plan of the CSD, 2009) includes a series of measures at three levels, taking into account the different groups of the Spanish population and their access to the practice of physical activity and sport:

1. Basic: $A+D$ and Health, $A+D$ at School Age.

2. Specific Groups: $A+D$ in the Labour Area, A+D in the University, $A+D$ and Disability, $A+D$ and Seniors, $A+D$ and Social Inclusion.

3. Transversal: A + D and Woman.

The existing sports promotion actions at this level of the State Administration are:

Inclusive Sport Program. This plan was incorporated into the 2018 General State Budget Law, also granting the status of an event of exceptional public interest, which means tax benefits. The program seeks to promote the sport of people with disabilities as a tool for their social inclusion and has an initial duration of three years until 2021.

Inclusive Sports Table. In October 2018, the Higher Sports Council set up this working group in which administrations at national, regional and local level are represented, together with the different Spanish federations of athletes with disabilities and the Spanish Paralympic Committee, with the aim of establishing a roadmap for the future of sports for PwD, making contributions to a future Law on Sports and advising on the management of the aforementioned Inclusive Sport Program.

\section{6.- DISCUSSION}

Aim of this study was offer a briefly but exhaustive view of how protection and integration of people with disability are guaranteed in Spanish context. We believe that two main arguments emerge from our analysis. The first pertains to the acknowledge of rights of persons with disability how rights fundamentals and, therefore, officially explained in the highest Spanish national legal document, namely the Constitutional Chart. However, here it is not simply the ascertaining that when Spanish Constitutional Chart was born it contained a refers to disabled persons but, importantly, that the way toward the definitive accomplishment of social model of disability will enshrined in a new constitutional article. The Olivenza report 2019 offer us a draft of this new article 49:

People with disability are holders of the rights and duties provided for in this Title in conditions of freedom and equality that is real and effective, without discrimination.

Public authorities will carry out the necessary policies to guarantee the full personal autonomy and social inclusion of people with disabilities. These policies will respect their free choices and preferences, and will be adopted with the participation of organization representing people with disabilities. Particular attention will be paid to the specific needs of women and girls with disabilities.

The reinforced protection of persons with disabilities will be regulated for the full exercise of their rights and duties.

People with disabilities enjoy the protection provided in international agreements that protect their rights.

As we can observe, this new article embodies in few but important words concepts and measures developed in 40 years of policies. In Spain, hence, rights of disabled people were born since the act constitutive in 1978 that scored the end of a dramatic period of civil war and dictature- and will be fully implemented in this new con-

International Journal of Developmental and Educational Psychology 
stitutional norm making definitively protection and integration of disabled people as fundamental rights. However, this process would not have been possible without the integration of national norms with international legislation. This is the second main argument that it seems inseparable from the first. If Spain actually holds an advanced legal system for disability, is due because rights of disabled people have grown as an international imperative that -as for other fundamental rights- we must appreciate but especially we must defend against obscurantist attacks that - unfortunately- are currently still present.

\section{REFERENCES}

Egido, E. B. (2006). Las políticas para la promoción y protección de los derechos de las personas con discapacidad. Revista general de información y documentación, 16(1), 29-37.

Jiménez, A. \& Huete, A. (2010). Políticas públicas sobre discapacidad en España. Hacia una perspectiva basada en los derechos. Política y Sociedad, 47(1), 137-152.

Haug, P. (2017). Understanding inclusive education: ideals and reality. Scandinavian Journal of Disability Research, 19(3), 206-217. https://doi.org/10.1080/15017419.2016.1224778

Huete, A., Huete, MํaA. \& Martín, A. (2015). Institucionalización de las personas con discapacidad en España. Madrid: Observatorio Estatal de la discapacidad.

Hvinden, B., \& Halvorsen, R. (2003). Which way for European disability policy?. Scandinavian Journal of Disability Research, 5(3), 296-312. https://doi.org/10.1080/15017410309512631

Informe Olivenza 2019, 0. E. (2019). sobre la situación general de la discapacidad en España.

Lord, J. E., \& Stein, M. A. (2008). The domestic incorporation of human rights law and the United Nations Convention on the Rights of Persons with Disabilities. Wash. L. Rev., 83, 449.

Lorenzo García, R. D. L., \& Palacios, A. (2011). Los grandes hitos de la protección jurídica de las personas con discapacidad en los albores del siglo XXI. Documentación Administrativa, (271-272). https://doi.org/10.24965/da.v0i271-272.5674

Martínez-Pujalte, A. L. (2016). Derechos fundamentales y discapacidad. Madrid: Ediciones Cinca.

Martínez-Ferrer, J.0. (2004). Paper de l'actividad física i de l'esport adaptat en la normalizació de les persones discapacitades. Aloma: Revista de Psicologia, Ciències de l'Educació i de l'Esport, 13, 13 - 23.

Martínez-Ferrer, J.0. (2010). Apuntes de Deporte Adaptado y Paraolimpismo. Máster de Salut y Actividad Física curso 2010-2011. FPCE i E. Blanquerna, Universitat Ramón Llull.

Toboso-Martín, M. (2013). De los discursos actuales sobre la discapacidad en España. Política y Sociedad, $50(2), 681-706$.

Verdugo, M.A., Vicent, C., Campo, M. \& Jordán de Urríes, B. (2001). Definiciones de discapacidad en España: un análisis de la normativa y la legislación más relevante. Salamanca: Servicio de Información sobre Discapacidad (SID).

Waldschmidt, A. (2009). Disability policy of the European Union: The supranational level. Alter, 3(1), 8-23. https://doi.org/10.1016/j.alter.2008.12.002

\section{NOTES}

1 This article is the result of the European Erasmus PLUS Project (Bottom-up Sport Partnership "B-SPORT +" Project Number - 613508-Epp-1-2019-1-Es-Spo-Scp) granted to various partners, among others the International Association Childhood, Adolescence, Adults and Disability Psychology (INFAD) 